\title{
PERLINDUNGAN HUKUM ATAS HAK KONSTITUSIONAL PARA PENGANUT AGAMA-AGAMA LOKAL DI INDONESIA
}

\author{
Muhammad Dahlan \\ Airin Liemanto \\ Fakultas Hukum Universitas Brawijaya \\ Jl. M.T. Haryono 169 Malang \\ Email: dahlan.fhub@gmail.com
}

\begin{abstract}
At this time there are still many local religions that have not been or are not recognized as official religions in Indonesia, such as Zen, Samin, Baduy. On the other hand, Article 28E and Article 29 paragraph (1) Indonesian Constitution guarantees freedom to every citizen to profess religion and to worship according to their respective beliefs, along with the state's obligation to provide legal protection on the constitutional rights. This paper aims to present the concept of the legal protection of the constitutional rights of the adherents of local religions in Indonesia by first outlining the relationship between religion and the state during the Old Order and New Order. The historical search will be the foundation for the reconceptualization of legal protection of constitutional rights of the local religious believers by putting them in the context of the state of law and democracy. This is a normative research. The results of this research is to advice regarding legal protection in the form of rights and obligations as well as equal treatment of all religions, both local religions and religions that have been officially registered in the relevant ministries, with the aim of fulfilling the constitutional rights of religion that is fair to all citizens of Indonesia.
\end{abstract}

Key words: constitutional rights, legal protection, civil religion

\begin{abstract}
Abstrak
Saat ini masih banyak agama-agama lokal (local religions - sebagai terjemah dari civil relegions; agama yang dianut oleh warga negara) yang belum diakui oleh negara. Padahal pada Pasal 28E dan Pasal 29 ayat (1) Undang-Undang Dasar Negara Republik Indonesia Tahun 1945 telah memberikan jaminan kebebasan kepada setiap warga negara untuk memeluk agama dan beribadah sesuai dengan keyakinan masing-masing, disertai dengan kewajiban negara melindungi setiap warga negara untuk beribadah sesuai dengan keyakinan masing-masing, tanpa terkecuali agama lokal. Oleh karenanya sudah menjadi kewajiban bagi negara melindungi dan menjamin kebebasan warga negaranya yang memeluk kepercayaan lokal. Tulisan ini bertujuan untuk mengetengahkan konsep perlindungan hukum atas hak konstitusional para penganut agama-agama lokal di Indonesia dengan menguraikan terlebih dahulu hubungan antara agama dan negara selama rezim Orde Lama dan Orde Baru. Penelusuran historis tersebut akan menjadi pijakan bagi rekonseptualisasi perlindungan hukum atas hak konstitusional para penganut agama lokal dengan meletakkannya dalam konteks negara hukum dan demokrasi. Tulisan ini didasarkan pada sebuah penelitian yuridis normatif dengan menggali bahan hukum, dan didukung data valid tentang hal-hal terkait. Penelitian tersebut menemukan bahwa perlindungan hukum dalam bentuk pemberian hak dan kewajiban serta perlakuan yang sama terhadap setiap pemeluk agama, baik agama lokal maupun agama yang telah terdaftar secara
\end{abstract}


resmi di Kementerian terkait, dengan tujuan pemenuhan hak konstitusional beragama yang adil bagi seluruh warga negara Indonesia.

Kata kunci: hak konstitusional, perlindungan hukum, agama-agama lokal

\section{Latar Belakang}

Indonesia merupakan negara yang berwatak kosmopolitan. ${ }^{1} \quad$ Unsur paling dominan dalam kosmopolitanisme ini adalah kehidupan beragama yang eklektik, di mana masyarakat Indonesia mampu mengembangkan pemikiran filsafatnya sendiri dengan memilah dari berbagai sumber yang telah dilalui selama berabad-abad. Watak ini dapat dilihat dari realitas keberagaman agama dan aliran kepercayaan yang tumbuh subur sebagai hasil dari pluralisasi. Terdapat beberapa agama dan puluhan bahkan ratusan aliran kepercayaan yang masih hidup dan berkembang di masyarakat. ${ }^{2}$

Sejarah panjang watak kosmopolitan yang mengedepankan semangat toleransi dalam kehidupan beragama di nusantara telah dimulai pada zaman Kerajaan Demak. Demak yang merupakan negara Islam mendasarkan pemerintahannya pada syari'at Islam. Dalam pemerintahan empat raja yang pertama, yakni Raden Fatah, Pati Unus, Trenggono, dan Sultan
Hadiwijaya masih terdapat agama resmi yakni agama Islam. Namun pada periode berikutnya, pada saat Sultan Hadiwijaya dikalahkan oleh Panembahan Senopati Ing Ngalono Sayyidin Panatagama, yakni Abdurrahman Sutawijaya, pada saat itu kemudian muncul adanya pemberian tempat pada sesuatu yang bukan agama, yakni Kepercayaan kepada Tuhan Yang Maha Esa. ${ }^{3}$

Selama berabad-abad sampai saat ini, di nusantara terdapat tidak kurang dari 400 (empat ratus) aliran kepercayaan kepada Tuhan Yang Maha Esa yang masih eksis. ${ }^{4}$ Beberapa aliran kepercayaan tersebut antara lain: agama Baha'i, Paguyuban Sumarah, agama Pran-Suh, agama Sapta Darma, agama Jawa Asli, Kawula Warga Naluri, Paguyuban Ngesti Tunggal, Ngelmu Beja-Mulur Mungkret, Ilmu Sejati Prawiro Sudarso, Paguyuban Pambuka Das Sanga, dan lain-lain. ${ }^{5}$ Berdasarkan hasil sensus pada Tahun 1930 dikeluarkan data mengenai jumlah penduduk Indonesia yakni total berjumlah 60,7 juta jiwa. Berdasarkan

1 Kosmopolitanisme ditandai dengan unsur-unsur yang dominan seperti hilangnya batas etnis, kuatnya pluralitas budaya, dan heterogenitas politik. Abdurrahman Wahid, Islam Kosmopolitan: Nilai-Nilai Indonesia dan Transformasi Kebudayaan, (Jakarta: The Wahid Institute, 2007), hlm. 9.

2 Wahyu Pramudya, "Pluralitas Agama: Tantangan "Baru" bagi Pendidikan Keagamaan di Indonesia", Varitas, Volume 6, (2005): 277.

3 Abdurrahman Wahid, Mengurai Hubungan Agama dan Negara, (Jakarta: Gramedia, 1999), hlm. 105.

4 Chandra Setiawan, Keragaman Budaya Spiritual sebagai Pemersatu Bangsa dalam buku Laporan Gelar Budaya Spiritual dan Kepercayaan Komunitas Adat, (Jakarta: Direktorat Jenderal Nilai Budaya Seni dan Film, Direktorat Kepercayaan Terhadap Tuhan Yang Maha Esa, 2006), hlm. 153.

5 Hilman Hadikusuma, Antropologi Agama Bagian I (Pendekatan Budaya terhadap Aliran Kepercayaan, Agama Hindu, Budha, Kong Hu Cu, di Indonesia), (Bandung: Citra Aditya Bakti, 1993), hlm. 98-147. 
klasifikasi keberagaman beragamanya, terdapat 29,5 juta $(48,7 \%)$ yang beragama Islam. Sedangkan jumlah penganut agama asli masih mencapai 28,6 juta $(47,2 \%){ }^{6}$

Aliran kepercayaan dan agama-agama adat ini lazim disebut sebagai indigenous religions, Jhon A. Grim dalam tulisannya menyebutkan bahwa agama-agama adat seringkali tidak berpangkal kepada agama dunia (world religion) seperti Islam, Katolik, Kristen, Hindu, Budha, Yahudi, dan lainnya. ${ }^{7}$ Walaupun dalam kasus yang lain ditemukan fakta bahwa indigenous religions ini juga sangat dipengaruhi oleh ajaran agama-agama dunia, dan mengalami peleburan dengan kepercayaan lokal.

Pluralitas yang dimiliki oleh bangsa Indonesia menunjukkan bahwa tradisi toleransi ini sebenarnya sudah terbangun secara alami ditengah-tengah masyarakat terlebih dahulu sebelum hadirnya agama. Dengan demikian, pengakuan dan toleransi tersebut bukan hanya untuk agama yang berbeda, tetapi juga untuk aliran kepercayaan. Hal ini penting diperhatikan sebagai pengalaman historis bangsa Indonesia yang akan mempengaruhi pola pikir bangsa di masa mendatang. Suatu bangsa tidak mungkin mengembangkan tradisi baru yang total terpisah dari akar-akar kesejarahannya. $^{8}$
Pemikiran yang berpijak dari akar kesejarahan inilah yang mengilhami para founding people bangsa Indonesia untuk merumuskan Pancasila sebagai dasar kehidupan berbangsa dan bernegara. Selain itu, kedudukan Pancasila juga sebagai pandangan hidup bangsa. Hal ini berarti Pancasila sebagai penuntun dan petunjuk arah bagi bangsa Indonesia dalam semua kegiatan dan aktivitas hidup serta kehidupan di segala bidang. ${ }^{9}$

Sila Ketuhanan Yang Maha Esa merupakan sila yang sangat penting bagi kehidupan bangsa Indonesia. Sila Ketuhanan mencerminkan komitmen bangsa Indonesia untuk membangun landasan moral yang kuat dan budi pekerti yang luhur. Seluruh warga negara Indonesia bebas memeluk agama dan kepercayaan masing-masing dengan saling menghormati hak beragama dan berkeyakinan orang lain dengan penuh toleransi. Dalam Sidang BPUPKI tanggal 1 Juni 1945, Soekarno menyatakan:
[...] Hendaknya negara Indonesia ialah negara yang tiap-tiap orangnya dapat menyembah Tuhannya dengan cara yang leluasa. Segenap rakyat hendaknya ber-Tuhan secara berkebudayaan, yakni dengan tiada "egoisme-agama". Dan hendaknya Negara Indonesia satu Negara yang berTuhan. ${ }^{10}$

6 Rachmat Subagya, Agama Asli Indonesia, (Jakarta: Sinar Harapan dan Yayasan Cipta Loka Caraka, 1981), hlm. 241.

7 Jhon A. Grim, Indigenous Tradition and Ecology, (USA: Yale University, Center for Respect of Life and Environment, published in Earth Ethics 10, no.1, Fall 1998).

8 Abdurrahman Wahid, Mengurai Hubungan..., op.cit., hlm. 105-106.

9 Darji Darmodiharjo, Pancasila dalam Beberapa Perspektif, (Jakarta: Aries Lima, 1983), hlm. 37.

10 Iman Toto K. Rahardjo dan Herdianto WK (Eds), Bung Karno Wacana Konstitusi dan Demokrasi: Kenangan 100 Tahun Bung Karno, (Jakarta: Grasindo, 2001), hlm. 35. 
Sedangkan menurut Muh. Yamin, yang mengemukakan dasar Peri Ketuhanan menyatakan bahwa:

[...] bahwa bangsa Indonesia yang akan bernegara merdeka itu ialah bangsa yang beradaban luhur, dan peradabannya itu mempunyai Tuhan Yang Maha Esa. Oleh sebab itu, maka dengan sendirinya kita insaf, bahwa Negara Kesejahteraan Indonesia Merdeka itu akan berkeTuhanan. Tuhan akan melindungi Negara Indonesia Merdeka itu. ${ }^{11}$

Perwujudan terhadap nilai-nilai Pancasila ini dituangkan dalam materi muatan UndangUndang Dasar Negara Republik Indoneisa Tahun 1945 (yang selanjutnya disebut dengan UUD NRI 1945. UUD NRI 1945 memiliki sejarah yang panjang dalam penegakan hak asasi manusia. Pada awal disahkannya UUD NRI 1945 sebenarnya tidak banyak memberikan perhatian kepada hak asasi manusia (HAM). UUD NRI 1945 hanya berbicara mengenai HAM secara universal dalam 2 hal, yakni Sila kedua Pancasila yang meletakkan asas "kemanusiaan yang adil dan beradab" dan Pasal 29 ayat (2) yang memberikan jaminan "kemerdekaan tiap-tiap penduduk untuk memeluk agamanya masingmasing dan beribadah menurut agama dan kepercayaannya itu".

SelebihnyaUUDNRI1945 hanya berbicara mengenai Hak Warga Negara (HAW/HAM partikularistik). Antara HAM dan HAW jelas berbeda sebab jika HAM bersifat melekat secara kondrati yang tidak dapat dipindah, diambil, atau dialihkan, maka HAW hanya mungkin diperoleh karena seseorang memiliki status sebagai warga negara. Hal ini menjadi satu legitimiasi penting terhadap kebebasan baragama dan menganut aliran kepercayaan apapun. $^{12}$

Muncul masalah saat legitimasi konstitusi ini menjadi terbatas dengan dikeluarkannya Undang-Undang Nomor 1.Pn.Ps. Tahun 1965 tentang Pencegahan Penyalahgunaan dan/atau Penodaaan Agama, yang hanya mengakui 5 (lima) agama resmi yang berlaku di Indonesia. Sampai saat ini, banyak kepercayaan lokal yang belum diakui oleh pemerintah, sehingga mereka tidak mendapatkan hak-haknya, contohnya untuk mencantumkan agama yang mereka anut di Akta Kelahiran, KTP, dan sebagainya. Bahkan pada tahun 1971, Jaksa Agung melaporkan sebanyak 167 (seratus enam puluh tujuh) aliran kepercayaan dilarang di Indonesia. ${ }^{13}$

Banyak tokoh-tokoh agama yang telah memperjuangkan haknya untuk mendapatkan legitimasi dari negara. Salah satunya dilakukan oleh Ketua Parmalim Toba-Samosir (Tobasa, Sumatera Utara). Pada tanggal 21 Maret 2005, Raja Marnakkok Naipospos menyampaikan terdapat 1.500 kepala keluarga atau \pm 6.000 jiwa yang menganut kepercayaan Parmalim

\footnotetext{
11 Muh. Yamin, Risalah Sidang Badan Penyidik Usaha-Usaha Persiapan Kemerdekaan Indonesia (BPUPKI), (Jakarta: Panitia Persiapan Kemerdekaan Indonesia (PPKI), Sekretariat Negara Republik Indonesia, 1992), hlm. 13 .

12 Moh. Mahfud MD, Hukum dan Pilar-Pilar Demokrasi, (Yogyakarta: Gama Media, 1999), hlm. 107.

13 Rachmat Subagya, Agama Asli..., op.cit., hlm. 251.
} 
di Tobasa. Untuk mendapatkan dokumen atau akta tertentu, biasanya mereka harus memberi sesuatu kepada petugas.

Berbagai upaya untuk bisa mendapatkan pengakuan telah dilakukan oleh para tokoh Parmalim, salah satunya yakni menemui DPRD Toba-Samosir. Namun upaya ini gagal. Hal yang sama juga terjadi pada penganut agama-agama lokal lainnya, seperti Sunda Wiwitan yang dianut oleh masyarakat adat Baduy. Pangeran Djatikusumah, tokoh agama yang memperjuangkan agama Sunda Wiwitan, juga tidak berhasil mendapatkan pengakuan dari pemerintah bagi masyarakat Baduy. ${ }^{14}$

Dengan banyaknya gelombang tuntutan dari kepercayaan-kepercayaan lokal, pemerintah seharusnya merespon dengan memberikan pengakuan dan perlindungan terhadap mereka. Hal ini bersesuaian dengan Pasal 28 I ayat (4) UUD NRI 1945 yang menyatakan negara, terutama pemerintah bertanggung jawab terhadap perlindungan, pemajuan, penegakan, dan pemenuhan hak asasi manusia. Dengan demikian, idealnya pemerintah seharusnya membuat kebijakan yang mempertimbangkan sosiokultur, mengakomodasi semua lini dan memberikan perlindungan hukum terhadap hak-hak konstitusional warga negara, serta mengusahakan pencapaian keadilan sosial.

Istilahagamasipilpertamakalidiungkapkan oleh J.J. Rousseau melalui konsep kontrak sosial. Dalam magnum opus-nya, On Social Contract, Buku IV, Rosseau menyinggung tentang apa yang ia maksud sebagai agama sipil, dengan penjabaran yang masih sangat sederhana. ${ }^{15}$ Awalnya, Rousseau melihat ada dua kategori agama yang menurutnya tidak sesuai dengan kebutuhan masyarakat; agama manusia dan agama masyarakat. Rousseau juga menyinggung tentang agama yang ketiga. Tentang model ketiga itu, Rousseau tidak memaparkannya secara detail, tapi ia melihat bahwa tiga agama yang ia ulas hampir semuanya tidak bisa dijalankan secara baik dalam sebuah komunitas masyarakat. ${ }^{16}$

Robert N. Bellah ${ }^{17}$ menggambarkan konsep civil religion dengan perspektif yang khas. Ia menulis dalam bukunya yang berjudul "The Broken Covenant: American Civil Religion in Time of Trial" bahwa agama sipil adalah elemen dasar warga Amerika Serikat yang sangat bermanfaat dalam membangun tata kehidupan bersama. Bellah menelaah dasar kehidupan masyarakat Amerika ketika perkembangan kehidupan mereka tidak lepas dari kehadiran"momen bersama" yang dikenal

14 Batara R. Hutagalung, “Ajaran Konghuchu Diakui Kembali Sebagai “Agama Resmi” Indonesia. Bagaimana dengan Agama-agama Asli Nusantara?”, http://batarahutagalung.blogspot.co.id/2006/06/ajaran-konghuchudiakui-kembali.html, diakses 10 Maret 2013.

15 Jean-Jacques Rousseau, terjemahan G.D.H. Cole, On Social Contract, (New York: Dover Publications, 2003), p. 93.

16 Ibid.

17 Robert N Bellah, The Broken Covenant: American Civil Religion in Time of Trial, (Chicago: University of Chicago Press, 1992), p. 3. 
sebagai agama sipil. Menurut Bellah, agama sipil adalah dimensi keagamaan publik yang terekspresikan dalam seperangkat keyakinan, simbol dan ritual. ${ }^{18}$ Tokoh lain, Durkheim menyatakan keyakinan-keyakinan keagamaan merupakan refleksi dari masyarakat itu sendiri, dan dengan ritual keagamaan solidaritas kelompok diperkuat dan tatanan moral dipertegas kembali. ${ }^{19}$

Di lain pihak, Nur Syam ${ }^{20}$ memiliki pendapat yang berbeda. Syam memahami agama sipil (dalam wilayah publik) terbatas pada nilai dan semangatnya, bukan dalam bentuk formal. Agama sipil hadir sebagai kenyataan sejarah yang terus berproses untuk menemukan kebenaran tidak terbatas yang bermanfaat bagi manusia dan alam semesta. Syam menolak agama lokal dijadikan sebagai ajaran kaku yang dogmatis atau etika yang eksklusif.

Konsep tentang agama sipil terus berkembang. Sebagian kelompok menempatkan agama di tengah-tengah perubahan sosial. Pemikiran ini berasal dari konsep agama sipil bangsa Amerika, yang menempatkan agama dalam masyarakat modern sebagai sandaran transendental. Jika kondisi masyaraktnya majemuk, maka agama sipil dapat diekspresikan dalam bentuk yang tidak formal, namun bersifat substansial. ${ }^{21}$

Meminjam batasan agama yang dikemukakan oleh Durkheim bahwa agama adalah sistem keyakinan dan praktik terhadap hal-hal yang sakral, yakni keyakinan dan praktik yang membentuk suatu moral komunitas pemeluknya. Moral komunitas ini memperlihatkan bahwa agama berfungsi sebagai perekat atau kohesi sosial antara satu sama lain yang mengintegrasikan manusia secara kolektif. Dengan kata lain manusia berada dalam posisi pasif yang diatur oleh satu sistem moral yang terintegrasi dalam mekanisme kelembagaan masyarakat. ${ }^{22}$

Komaruddin Hidayat ${ }^{23}$ menunjukkan mekanisme tersebut dengan menyatakan ada hubungan yang sangat erat antara agama dan budaya yang kemudian tampil dalam berbagai bentuk festival keagamaan, namun sangat kental dengan warna budaya lokalnya sekalipun pesan dan pemaknaannya selalu

18 Ibid. Bandingkan dengan definisi John A. Coleman tentang agama sipil. Menurut Coleman, civil religion is the mystic chord of communal memory which ties together both a nation's citizenry and the episodes of its history into a meaningful identity by using significant national beliefs, events, persons, places, or documents to serve as symbolic repositories of the special vocational significance of the nation -state in the light of a more ultimate or transcendent bar of judgment: ethical ideals, humanity, world history, being, the universe or God. John Coleman, An American Strategic Theology, (New York: Paulist Press, 1982), p. 109.

19 Durkheim dalam Abdullah dkk, Agama dan Kearifan Lokal Dalam Tantangan Global, (Yogyakarta: Pustaka Pelajar, 2008), hlm. 4.

20 H. Nur Syam, "NU, Pancasila Dan Civil Religion”, http://pensa-sb.info/wp-content/uploads/2011/01/NU_ and Civil Religion.pdf, diakses 7 Desember 2013.

21 Ibid., hlm. 3.

22 Durkheim dalam Abdullah dkk, op.cit., hlm. 4.

23 Komaruddin Hidayat dalam M. Thoyibi, Yayah Khisbiyah \& Abdullah Aly (Eds), Sinergi Agama dan Budaya Lokal: Dialektika Muhammadiyah dan Seni Lokal, (Malang: Muhammadiyah University Press, 2003), hlm. 9. 
ditarik ke tataran universal. Hal ini terkait dengan hakikat manusia dengan kemanusiaan yang bersifat homo ludens, karena senang dengan ragam permainan, homoreligious, karena selalu mencari dan merindukan Tuhan, dan juga homofestivus mengingat kegemarannya berfestival. ${ }^{24}$

Lebih lanjut, Hidayat berpendapat bahwa hendaknya agama mampu mentransendensikan diri, yakni memposisikan diri di atas pluralitas budaya dan bangsa. Setelah, berada di atas, agama harus mampu memberi visi dan pencerahan kemanusiaan dalam lingkup kebudayaan dan kebangsaan. Pada akhirnya, gerakan keagamaan akan berujung pada gerakan kebudayaan, karena perwujudan akhir dan perilaku manusia akan termanifestasikan pada ranah budaya. Jika suatu agama tidak mampu mewujudkan diri dalam bentuk budaya, maka agama tersebut akan ditinggalkan oleh pengikutnya. Sebaliknya, gerakan kebudayaan yang tidak dimuati dengan unsur keagamaan juga tidak akan mampu memperoleh dukungan untuk selama-lamanya. Bagaimanapun, sejarah lah yang nanti akan membuktikan dan mengukur secara empiris tentang eksistensi keberadaan suatu agama. ${ }^{25}$

Tedi Kholiludin ${ }^{26}$ mencoba memberi kesimpulan terkait konsep agama sipil. Ia mengatakan bahwa jika kesadaran masyarakat menjadi pusat, ada dua bangunan teori mengenai agama sipil. Pertama adalah Teori Sentrifugal $^{27}$ ketika konstruksi agama sipil bergerak "ke atas," dari masyarakat menuju idealitas bernegara seperti yang digambarkan Rousseau. Kedua, Teori Sentripetal yakni kesadaran kolektif, civic morals, sebagai poros dari pandangan tersebut dengan merujuk pada pandangan Durkheim. Gambaran tentang bagaimana gabungan dari dua konsepsi teoretik ini bisa kita dapati dalam paparan Bellah tentang agama sipil di Amerika.

\section{Pembahasan}

\section{A. Hubungan Antara Agama dan Negara di Indonesia}

\section{Orde lama}

Perumusan tentang hubungan antara agama dan negara telah menjadi perdebatan yang sengit sebelum Indonesia merdeka. Diskursus ini semakin terlihat jelas dalam sidang BPUPKI, di mana terdapat 2 kubu yang berbeda yakni kubu nasionalis sekuler dan kubu nasionalis Islam. Tokoh yang mewakili nasionalis sekuler antara lain Soekarno, Mohammad Hatta dan Soepomo. Sedangkan nasionalis Islam diwakili oleh M. Natsir, Ki Bagus Hadikusumo, Wahid Hasjim, dan A. Moechlis.

Melalui perdebtan yang panjang, pada

24 Ibid.

25 Donald Eugene Smith, Agama dan Modernisasi Politik: Suatu Kajian Analitis, (Bandung: Rajawali, 1985).

26 Tedi Kholiluddin, "Agama Sipil Sebagai Fenomena Episodik (Problem dan Tantangan Agama Sipil di Indonesia)", http://cdn.salihara.org/media /documents/2013/09/11/m/a/makalah_tedi_kholiludin_agama_sipil. pdf, diakses 7 Desember 2013.

27 Dalam konteks ini, ia memaparkan bahwa masyarakat adalah inti pertumbuhan agama. 
tanggal 22 Juni telah dicapai kesepakatan tentang Pembukaan Undang-undang Dasar atau yang lebih dikenal dengan Piagam Jakarta (The Jakarta Charter). Dalam Piagam Jakarta ini telah ditetapkan tujuh kata yang berbunyi "dengan kewajiban menjalankan syariat Islam bagi pemeluk-pemeluknya". Hal ini merupakan kemenangan politik kelompok Islam. ${ }^{28}$

Piagam Jakarta menjadi kesepakatan yang sangat penting karena bagi kubu nasionalis Islam yang diwakili oleh pemikiran $\mathrm{M}$. Natsir berpandangan Islam sebagai filsafat kehidupan sekaligus sebagai ideologi. Hal ini membawa konsekuensi di mana Islam secara ideal berperan sebagai pengatur kehidupan penganutnya baik yang meyangkut ritual maupun kehidupan duniawi. Pola pendekatan yang digunakan oleh Natsir bersifat legal formalistik, di mana syariat Islam hanya dapat terlaksana bila negara ikut memaksakan hukum dan peraturan agama. Oleh karena itu, cara untuk mewujudkan ajaran-ajaran agama Islam secara sempurna harus menggunakan kekuasaan yang ada pada negara dengan mempersatukan hubungan antara agama dan negara. ${ }^{29}$

Hal ini berbeda dengan pandangan Soekarno yang mewakili kubu nasionalis sekuler. Titik tolak pemikiran Soekarno yakni berupaya untuk menjadikan penghayatan ajaran agama sebagai usaha pembudayaan. Secara prinsip Islam telah diterima oleh umat Islam sebagai kebenaran yang berasal dari Allah. Namun titik tekan persoalannya adalah bagaimana ajaran ini dapat membudaya dalam kehidupan umat Islam, sehingga menjadi bagian yang tidak terpisahkan dari kehidupannya. Selain itu Soekarno juga menyatakan tidak ada ijma (kesepakatan) para ulama tentang persatuan agama dan negara. ${ }^{30}$

Setelah melalui proses yang panjang, diskursus ini mencapai keputusan akhir pada tanggal 18 Agustus 1945. Dalam rapat PPKI tersebut, terdapat beberapa perubahan penting yang sangat mendasar dalam kaitan dengan hubungan antara agama dan negara. Berikut empat perubahan mendasar yang disampaikan oleh Mohammad Hatta: ${ }^{31}$

1. Kata "Mukaddimah" diganti dengan "Pembukaan"

2. Dalam Preambule yang tercantum di PiagamJakarta,anakkalimat:"Ketuhanan, dengan kewajiban menjalankan Syaria'at Islam bagi pemeluk pemeluknya", diubah menjadi"berdasarkan atas Ketuhanan Yang Maha Esa".

3. Pasal 6 alinea (1), "Presiden ialah orang Indonesia asli dan beragama Islam", kata-kata "dan beragama Islam" dihapus.

4. Konsekuensi dari perubahan anak kalimat dalam preambule, maka pada

28 Amos Sukamto, "Ketegangan Antar Kelompok Agama pada Masa Orde Lama sampai Awal Orde Baru: Dari Konflik Perumusan Ideologi Negara Sampai Konflik Fisik”, Jurnal Teologi Indonesia 1/1, (Juli 2013 ): 27.

29 M. Ridwan Lubis, Sukarno dan Modernisme Islam, (Depok: Komunitas Bambu, 2010), hlm. 257-259.

30 Ibid., hlm. 259-262.

31 Endang Saifuddin Anshari, Piagam Jakarta 22 Juni 1945 dan Sejarah Konsensus Nasional antara Nasionalis Islami dan Nasionalis "Sekuler” tentang Dasar Negara Republik Indonesia 1945-1959, (Jakarta: Rajawali, 1986), hlm. 50-51. 
Pasal 29 ayat (1) diubah menjadi "Negara berdasarkan atas Ketuhanan Yang Maha Esa".

Penetapan konsep relasi hubungan antara agama dan negara ini telah membawa bangsa Indonesia ke dalam babak baru penegakan hak asasi manusia terutama dalam hal kebebasan beragama. Sejak tahun 1946, kebijakan pemerintah dalam bidang penataan dan pembinaan kehidupan keagamaan diarahkan pada dua misi penting, yakni: 1) menjamin kebebasan beragama; dan 2) mengembangkan sikap saling menghormati dan toleransi di antara para pemeluk berbagai agama demi terciptanya kerukunan. Oleh karena itu, untuk mencapai tujuan tersebut, pada 2 Januari 1946, pemerintah mengeluarkan kebijakan membentuk Departemen Agama. Secara umum, ada tiga fungsi dan tujuan utama Departemen Agama yaitu: 1) memberikan pelayanan-pelayahan keagamaan, 2) mengembangkan pendidikan agama, dan 3) membina kerukunan antar umat beragama. ${ }^{32}$

Meskipun Departemen Agama belum dapat menjalankan peranannya secara maksimal karena semua tenaga dicurahkan untuk mempertahankan kemerdekaan, namun dalam kaitan hubungan antar umat beragama, terdapat toleransi yang tinggi. Hal ini misalnya dapat dilihat agama Islam dan agama Kristen saling bekerjasama untuk mepertahankan kemerdekaan baik dalam pertempuan fisik, diplomasi, maupun di lingkungan pemerintahan. ${ }^{33}$

Dalam perkembangan berikutnya yang terjadi pada Tahun 1949, Republik dan B.F.O mengadakan Konferensi Inter-Indonesia di Yogyakarta (19-22 Juli 1949) dan di Jakarta (31 Juli- 2 Agustus 1949). Dalam kedua konferensi tersebut, telah dicapai kesepakatan dalam pokok-pokok tentang soal minoritas. Garis besar tentang hasil tersebut yakni mengambil keputusan di sekitar: ${ }^{34}$

1. Ketatanegaraan;

2. Keuangan dan perekonomian;

3. Keamanan;

4. Kebudayaan;

5. Pengajaran dan pendidikan;

6. Agama;

7. Pemuda.

Jaminan kebebasan beragama terhadap aliran kepercayaan ini menyebabkan kebangkitan yang signifikan. Pada Tahun 1951, untuk melakukan pengawasam, Kementerian Agama RI mendata aliranaliran kepercayaan baru, yakni sebanyak 73 kelompok. Tahun 1956, Departemen Agama di Yogyakarta menyatakan terdapat 63 kelompok aliran kepercayaan di Pulau Jawa, 35 kelompok tersebut berada di Jawa Tengah, 22 kelompok di jawa Barat dan 6 kelompok

32 Sofyan Hadi, "Relasi dan Reposisi Agama dan Negara (Tatapan Masa Depan Keberagamaan Di Indonesia)", Jurnal Millah Vol. X, No. 2, (Februari 2011): 235.

33 Jan S. Aritonang, Sejarah Perjumpaan Gereja dan Islam di Indonesia, Soegeng Hardiyanto, dkk (Eds), Agama dalam Dialog (Pencerahan, Perdamian dan Masa Depan), (Jakarta: BPK Gunung Mulia, 2003), hlm. 191.

34 M. Tabrani, Dalam Indonesia Merdeka: Soal-Soal Minoritoit, (Jakarta: Sin Po, 1950), hlm. 62-63.

35 Amos Sukamto, op.cit., hlm. 31. 
di Jawa Timur. Hingga tahun 1965 kelompok aliran kepercayaan ini telah mencapai jumlah \pm 300 kelompok. ${ }^{35}$

Melihat perkembangan tersebut, pada Tahun 1952 Departemen Agama yang didalamya mayoritas pejabat-pejabat yang beragama Islam, mengajukan usul tentang persyaratan minimum tentang agama, yakni: (1) adanya nabi; (2) ada kitab suci; dan (3) pengakuan internasional. Persyaratan ini tentu tidak menguntungkan bagi penganut aliran kepercayaan atau agama lokal, dan sematamata persyaratan ini ditujukan untuk menekan perkembangan aliran kepercayaan. ${ }^{36}$

Dalam rangka melakukan pengawasan terhadap berbagai aliran kepercayaan, pada Oktober 1954, Departemen Agama membentuk Pengawasan Aliran Kepercayaan Masyarakat (PAKEM). PAKEM bertugas untuk mengawasi gerakan-gerakan spiritual yang tidak sepaham dengan Islam. Afandi berpendapat bahwa PAKEM merupakan cara negara dalam melindungi agama. Sebaliknya, Mulder melihat PAKEM sebagai: "In hands of the Ministry of Religion, Pakem became the watchdog against utterly anti-Islamic spiritual movements", 37

Terlepas dari polemik yang berkembang tentang terbentuknya PAKEM, semenjak Undang-Undang Dasar 1950 tidak berlaku lagi sejak tanggal 5 Juli 1959 pemerintah semakin berupaya untuk mengatur kehidupan beragama yang ada di Indonesia. Pada tahun 1960, Majelis Permusyawaratan Rakyat Sementara (MPRS) mengeluarkan Ketetapan MPRS Nomor II/MPRS/1960, Lampiran A Bidang I angka 6 yakni terkait persoalan aliran kebatinan atau kepercayaan yang diberikan catatan khusus. Dengan adanya kebijakan ini, pemerintah berusaha untuk menyalurkan pandangan yang sehat dan ke arah Ketuhanan Yang Maha Esa. Dan demi melindungi agama-agama (yang diakui negara) dari berbagai aliran kepercayaan, maka lahirlah Penetapan Presiden Nomor 1/PNPS/1965 tentang Pencegahan Penyalahgunaan dan/atau Penodaan Agama.

Penetapan Presiden yang kelak menjadi Undang-Undang ini, akan menjadi landasan yuridis utama bagi banyak Undang-Undang dan peraturan lain di bidang keagamaan. Bagi penganut aliran kebatinan dan kepercayaan di luar keenam agama yang diakui, kebijakan ini sangat diskriminatif. Namun kebijakan tersebut terus berjalan karena Penetapan Presiden ini didukung oleh mayoritas agamaagama yang diakui negara. ${ }^{38}$

\section{Orde baru}

Masa Orde Baru ditandai dengan tekad untuk melaksanakan Pancasila danUUD Tahun 1945 secara murni dan konsekuen. Dalam gagasan perombakan struktur ketatanegaraan, hubungan antara agama dan negara menjadi

36 Ibid.

37 Ibid., hlm. 31-32.

38 Trisno S. Sutanto, Politik Kesetaraan, Elza Peldi Taher, dkk (Eds), Merayakan Kebebasan Beragama (Bunga Rampai 70 Tahun Djohan Effendi), (Jakarta: ICPR dan Kompas, 2009), hlm. 382-383. 
agenda yang mendesak untuk diatur. Selama periode Orde Baru, agama menjadi diskursus, di mana terjadi pertandingan antar beberapa rezim kebenaran yang dibela agama masingmasing yang mungkin tidak berjalan netral. Hal ini disebabkan karena yang satu lebih berkuasa dari yang lain, dukungan modal dan kekuasaan negara serta institusi sosial lainnya. Pertarungan ini menyebabkan adanya unsur pengabaian terhadap agama-agama lain yang tidak diakui oleh negara. Pada zaman Orde Baru, agama mendapat kontrol yang sangat ketat dengan cara dipilah, diorganisasikan dan didistribusikan berdasarkan cara tertentu. Cara ini terutama ditujukan untuk menghindarkan aliran-aliran kepercayaan tersebut dari ranah kekuasaan. ${ }^{39}$

Dalam mewujudkan visi pemerintah tersebut, maka dikeluarkanlah Instruksi Presiden Nomor 14 Tahun 1967 yang mengatur hanya ada 5 agama resmi yang diakui oleh negara yakni Islam, katolik, Kristen/Protestan, Hindu, dan Buddha. Hal ini didukung dengan dikeluarkannya Tap MPR Nomor IV/MPR/1978 tentang GBHN, ditambah Instruksi Mentri Agama Nomor 4 Tahun 1978 yang secara tegas menyatakan bahwa aliran kepercayaan bukan "agama"e, dan "agama" yang dimaksud pemerintah yakni hanya lima agama resmi yang disebutkan di atas. ${ }^{40}$
Sepanjang 32 tahun masa Orde Baru, maka jika dibahas lebih detail, terdapat 3 sifat hubungan antara negara dan Islam pada masa pemerintahan Orde Baru, antara lain:

1. Hubungan yang bersifat antagonostik (1967-1982)

Masa Orde Lama yang mengekang partaipartai Islam menyebabkan masa Orde Baru menjadi harapan bagi partai-partai Islam untuk kembali berperan dalam dunia politik. Namun setelah pemerintah Orde Baru memantapkan kekuasaannya, pemerintah segera melakukan kontrol yang lebih kuat terhadap kekuatan politik Islam, terutama kelompok radikal yang dikhawatirkan dapat menandingi kekuatan pemerintah. Hal ini dibuktikan dengan gagalnya pembentukan Partai Demokrasi Islam Indonesia dan rehabilitasi Masyumi. ${ }^{41}$

2. Hubungan yang bersifat resiprokal kritis (1982-1985)

Masa ini dimulai ketika pemerintah melemparkan gagasan tentang asas Tunggal Pancasila. Reaksi umat Islam cukup beragam. Secara umum, terdapat 3 reaksi yakni (1) menerima tanpa syarat, (2) menerima karena terpaksa, dan (3) menolak sama sekali. Pada titik inilah negara dan Islam belajar untuk saling memahami posisi masing-masing. ${ }^{42}$

39 Daniel Dhakidae, Cendekiawan dan Kekuasaan dalam Negara Orde Baru, (Jakarta: Gramedia Pustaka Utama, 2003), hlm. 513-514.

40 Laylatul Fittrya, “Tionghoa Dalam Diskriminasi Orde Baru Tahun 1967-2000”, AVATARA, e-Journal Pendidikan Sejarah, Fakultas Ilmu Sosial Universitas Negeri Surabaya, Vol. 1, No. 2, (Mei 2013): 163.

41 Abdul Aziz Thaba, Islam dan Negara dalam Politik Orde Baru, (Jakarta: Gema Insani Press, 1996), hlm. 240246.

42 Ibid., hlm. 262-265. 
3. Hubungan yang bersifat akomodatif yang dilakukan oleh negara. Dengan kata (1985-1994).

Setelah ormas Islam menerima asas tunggal Pancasila, maka muncul kebijakan-kebijakan yang bersifat akomodatif terhadap Islam antara lain dikeluarkannya kebijakan Menteri Pendidikan dan Kebudayaan menghapus larangan berjilbab di sekolah-sekolah. Perkembangan positif lainnya yakni disahkannya RUU Pendidikan Nasional, pengesahan RUU Peradilan Agama, pembentukan ICMI, pendirian bank Muamalat, dan lain-lain. ${ }^{43}$

\section{Orde Reformasi}

Reformasi menandai perjalanan penting hubungan antara agama dan negara di Indonesia. Perubahan UUD NRI Tahun 1945 menyebabkan pergeseran struktur norma hubungan agama dan negara yang dapat dilihat dari 2 aspek, yakni kebebasan dan persamaan. Aspek kebebasan, dapat ditinjau dari pasal 28 UUD NRI Tahun 1945:44

Berdasarkan penafsiran secara ekstensif, maka pada Pasal 28 E telah memberikan jaminan kepada agama-agama sipil yang ada di Indonesia. Sedangkan aspek persamaan akan terwujud apabila sudah tidak ada paksaan bagi para penganut Aliran-Aliran Kepercayaan lain, negara seharusnya mengeluarkan aturan yang melindungi agama-agama sipil, namun tidak berkewajiban untuk memberikan dukungan secara materiil. Hal ini berbeda dengan agama-agama resmi yang diakui oleh negara, dimana negara tidak hanya sekedar berkewajiban untuk melindungi melainkan juga harus mendukung secara materiil. ${ }^{45}$

Di samping adanya jaminan yang tegas dalam Konstitusi, agama juga memiliki peranan yang signifikan dalam kehidupan berbangsa dan bernegara. Hal ini dapat dilihat pada visi Indonesia 2012 yang diatur dalam TAP MPR Nomor VII/ MPR 2001 tentang Visi Indonesia Masa Depan. Pada pasal 2 Bab IV angka 1 diuraikan mengenai Visi Indonesia 2020, antara lain: ${ }^{46}$

a. Terwujudnya masyarakat yang beriman, yang bertakwa, berakhlak mulia

b. Terwujudnya toleransi intern dan antar umat beragama.

c. Terwujudnya penghormatan terhadap martabat kemanusiaan.

Melalui Perubahan UUD NRI Tahun 1945 dan penentuan Visi Indonesia 2020, membuka peluang perubahan dalam berbagai bidang, salah satunya yakni dalam bidang agama. Kebijakan penting yang perlu dicatat pada era reformasi yakni munculnya Undang-

43 Ibid., hlm. 278-279.

44 Mohamad Mova Al 'Afghani, op.cit., hlm. 14.

$45 \mathrm{Ibid}$.

46 Asasriwarni, Undang-undang No. 1 /PNPS/ th. 1965 tentang Pencegahan Penyalahgunaan dan/atau Penodaan Agama dari Perspektif Agama di Indonesia, Makalah disampaikan pada Kegiatan Kajian Putusan Mahkamah Konstitusi tentang Pencegahan Penyalahgunaan dan/ atau Penodaan Agama terhadap UUD 1945, Senin, 28 Juni 2010 di Hotel Inna Muara Padang, yang diadakan oleh Kementerian Hukum dan HAM RI (Direktorat Jenderal Perundang-undangan) Jakarta, hlm. 4. 
undang Nomor 39 Tahun 1999 tentang Hak Asasi Manusia, dikeluarkannya Keputusan Presiden Nomor 6 Tahun 2000 yang mencabut Instruksi Presiden No. 14 Tahun 1967 tentang Pelarangan Agama Konghucu di Indonesia. ${ }^{47}$ Dan masih banyak lagi peraturan perundangundangan lainnya yang dikeluarkan oleh pemerintah untuk menjamin kerukunan dan toleransi antar umat beragama.

Selain kebijakan nasional, Indonesia juga telah meratifikasi berbagai ketentuan internasional yang berkaitan dengan kebebasan beragama atau berkeyakinan. Kerangka hukum internasional tersebut antara lain: Universal Declaration of Human Rights, Declaration on The Eliminaton of All Forms of Intolerance and of Discrimination Based on Religion or Belief (Deklarasi Universal 1981), Komite Hak Asasi Manusia Komentar Umum, Undang-undang Nomor 11 Tahun 2005 tentang Pengesahan International Covenanton Economic, Social and Cultural Rights, Undang-undang Nomor 12 Tahun 2005 tentang Pengesahan International Covenant on Civil and Political Rights, Keputusan Presiden Nomor 36 Tahun 1990 tentang Pengesahan Convention on The Rights of The Child, dan ketentuan internasional lainnya. ${ }^{48}$
Pelaksanaan teknis untuk mewujudkan berbagai ketentuan peraturan perundangundangan coba diupayakan semaksimal mungkin oleh pemerintah. Kementerian agama lewat unit Pusat Kerukunan Umat Beragama (PKUB) telah membuat berbagai program dan strategi yang komprehensif untuk mewujudkan keharmonisan umat beragama, antara lain: 49

1. Inovasi dan pemantapan program keharmonisan umat beragama

2. Mengupayakan terbentuknya tenaga fungsional pemandu harmonisasi umat.

3. Program pengembangan wawasan multikultural.

4. Menggali berbagai kearifan lokal penopang harmonisasi.

5. Manjalin kemitraan aktif.

6. Pemberdayaan Forum Kerukunan Umat Beragama.

7. Pendekatan terhadap penganut paham radikal dan liberal.

8. Optimalisasi media.

9. Melaksanakan berbagi kegiatan riil yang langsung bersentuhan dengan kepentingan masyarakat luas.

10. Pelayanan terhadap umat Khonghucu.

47 Sofyan Hadi, op.cit., hlm. 239.

48 Nurkholis Hidayat, Muhamad Isnur, dan Febi Yonesta, Peradilan Kasus-Kasus Kebebasan Beragama dan Berkeyakinan (Rangkuman 8 Studi Kasus: Dampai, Pencapaian, Hambatan, dan Strategi), (Jakarta: LBH Jakarta, 2011), hlm. 21-27.

49 Achmad Gunaryo, "Kebijakan Kementerian Agama Dalam Pembinaan Kerukunan Umat", http://sultra. antaranews.com/berita/264132/kebijakan-kementerian-agama-dalam-pembinaan-kerukunan-umat, diakses 26 Juni 2013. 
11. Dialog.

12. Interfaith Dialogue.

B. Urgensi

Rekonseptualisasi

Perlindungan Hukum Terhadap

Hak-Hak Konstitusional Penganut

Agama Sipil di Indonesia

\section{Konsep perlindungan hukum terhadap agama-agama asli selama ini di Indonesia}

Kepentingan paling mendasar dari setiap warga negara adalah perlindungan terhadap hak-haknya sebagai manusia. Dalam Undang-undang No. 39 Tahun 1999 tentang Hak Asasi Manusia, HAM didefinisikan sebagai "seperangkat hak yang melekat pada hakikat dan keberadaan setiap manusia sebagai makhluk Tuhan Yang Maha Esa dan merupakan anugerah-Nya yang wajib dihormati, dijunjung tinggi, dan dilindungi oleh Negara, Hukum, Pemerintahan, dan setiap orang, demi kehormatan serta perlindungan harkat dan martabat manusia". Mengingat pentingnya hak asasi manusia ini, maka dalam UUD NRI Tahun 1945 dari awal terbentuknya, telah dicantumkan secara tegas dalam berbagai pasal. ${ }^{50}$

Namun, jika diperhatikan dengan sungguh-sungguh, hanya 1 ketentuan saja yang memang benar-benar memberikan jaminan konstitusional atas hak asasi manusia, yaitu
Pasal 29 Ayat (2) yang menyatakan, 'Negara menjamin kemerdekaan tiap-tiap penduduk untuk memeluk agamanya masing-masing dan untuk beribadat menurut agamanya dan kepercayaannya itu'. Sedangkan ketentuanketentuan yang lain, samasekali bukan rumusan tentang hak asasi manusia atau human rights, melainkan hanya ketentuan mengenai hak warga negara atau the citizens' Rights. $^{51}$

Baik dalam kerangka hukum nasional maupun internasional, kebebasan beragama merupakan hak asasi manusia yang tidak dapat dikurangi, dibatasi, atau diintervensi siapapun, dalam keadaan bagaimanapun. Yang dapat membatasi kebebasan beragama atau berkeyakinan hanya dibatasi pada lima alasan, yakni: ${ }^{52}$

1. Pembatasan demi keamanan publik.

2. Pembatasan untuk melindungi ketertiban masyarakat.

3. Pembatasan untuk melindungi kesehatan masyarakat.

4. Pembatasan untuk melindungi moral masyarakat.

5. Pembatasan untuk melindungi kebebasan mendasar dan kebebasan orang lain.

Di luar dari lima pembatasan tersebut, dalam konstruksi hukum perundang-undangan di Indonesia terdapat berbagai jaminan dalam menjalankan aktivitas kebebasan beragama

50 Jimly Asshiddiqie, Konstitusi dan..., loc.cit.

51 Ibid.

52 Nurkholis Hidayat, Muhamad Isnur, dan Febi Yonesta, Peradilan Kasus-Kasus Kebebasan Beragama dan Berkeyakinan (Rangkuman 8 Studi Kasus: Dampai, Pencapaian, Hambatan, dan Strategi), (Jakarta: LBH Jakarta, 2011), hlm. 30. 
atau berkeyakinan baik dalam kerangka hukum nasional maupun internasional.

Pancasila merupakan sistem filsafat yang tidak hanya menyangkut butir-butir sila, tetapi juga meliputi hakikat dari sila-sila yang merupakan dasar ontologis. Hal ini membawa konsekuensi Sila Ketuhanan Yang Maha Esa menjadi dasar ontologis, epistemologi dan aksiologi hubungan antara agama dan negara. Ketuhanan Yang Maha Esa merupakan prinsip yang lebih mendalam dari negara Indonesia dan merupakan tujuan akhir. Dengan kata lain, tujuan hidup manusia (warga negara) tidak hanya kemakmuran atau kesejahteraan yang diupayakan oleh negara saja, tetapi Tuhan Yang Maha Esa itu sendiri. Oleh karena itu, fungsi dan peranan agama di Indonesia mempunyai posisi yang sangat strategis dan penting. ${ }^{53}$

Abdurrahman Wahid memaparkan pemikirannya tentang merumuskan kembali hubungan antara agama dan negara. Gus Dur berpendapat dalam sudut pandang sejarah, terdapat hubungan yang bersifat dualisitik antara agama dan negara, di mana agama memberikan legitimasi kepada negara. ${ }^{54}$ Namun dengan menguatnya modernisasi dan globalisasi, maka hubungan dualistik yang dulunya telah terbina antara agama dan negara menjadi semakin tidak jelas.

Dalam rangka menegaskan kembali batasan hubungan antara agama dan negara, maka perlu ditekankan tentang indikator terlaksananya demokrasi. Demokrasi dikatakan berjalan apabila terpenuhinya nilai pembebasan, keadilan, dan persamaan. Pembebasan merupakan hak dasar, yang di dalamnya mencakup kebebasan berpendapat, berorganisasi dan berserikat. Lebih lanjut, nilai keadilan harus diwujudkan dalam segala bentuk, baik dalam bidang hukum, politik, ekonomi, sosial dan budaya. Sedangkan ruh demokrasi juga menuntut adanya persamaan derajat dan kedudukan bagi seluruh warga negara di depan hukum, tanpa memandang suku, agama, dan ras. Dalam rangka menjamin terlaksananya nilai-nilai tersebut, maka salah satu syarat yang harus dipenuhi yakni Konstitusi yang kokoh, agar seluruh kepentingan warga negara dapat terakomodasi tanpa adanya benturan. Pada akhirnya, negara demokrasi yang sukses memiliki konstitusi yang kokoh dan menjunjung tinggi nilai-nilai kemanusiaan, yang kemudian dikenal dengan demokrasi konstitusional. ${ }^{55}$

Posisi agama dalam kaitannya dengan demokrasi konstitusional merupakan sumber moral transendensi yang memunculkan kesadaran kolektif untuk memperjuangkan Pancasila sebagai dasar negara. Selain itu, agama juga berperan penting dalam kehidupan bermasyarakat, yang dapat berkontribusi dalam aspek ekonomi, sosial, politik, dan budaya. Dengan demikian, agama diharapkan dapat:

53 Armaidy Arwani, op.cit., hlm. 21.

54 Abdurrahman Wahid, Mengurai Hubungan Agama dan Negara, (Jakarta: Gramedia Widiasarana, 1999), hlm. 109.

55 Nur Kholisoh, Demokrasi Aja Kok Repot, (Yogyakarta: Pohon Jaya, 2012), hlm. 54. 
1. Meningkatkan kualitas sumber daya manusia.

2. Mendorong untuk meningkatkan partisipasi dalam berkarya dan berkreasi.

3. Menjadi sarana dalam mengurangi berbagai macam penyimpangan melalui nilai-nilai yang diajarkan.

Langkah konkret untuk melakukan rekonseptualisasi hubungan antara agama dan negara dapat dilakukan dengan merevisi berbagai peraturan perundang-undangan yang bersifat diskriminatif. Tercatat ada puluhan peraturan perundang-undangan yang bersifat diskriminatif terhadap agama sipil, antara lain: ${ }^{56}$

1. Instruksi Menteri Agama Nomor 4 Tahun 1978 tentang Kebijaksanaan mengenai Aliran-Aliran Kepercayaan.

2. Instruksi Menteri Agama RI Nomor 14 Tahun 1978 tentang Tindak Lanjut Kebijaksanaan mengenai Aliran-Aliran Kepercayaan.

3. Surat Menteri Agama kepada Gubernur/ KDH Tingkat I Jatim No. B/ 5943/ 78 tentang Masalah Menyangkut Aliran Kepercayaan.

4. Surat Keputusan Jaksa Agung RI on. Kep. 089/ J.A/9/ 1978 tentang Larangan Pengedaran/ Penggunaan Surat Kawin yang Dikeluarkan oleh Yayasan Pusat Srati Dharma Yogyakarta.

5. Surat Menteri Agama kepada Gubernur/ $\mathrm{KDH}$ Tingkat I Seluruh Indonesia no B.VI/ 11215/ 1978 perihal masalah
Penyebutan Agama, Perkawinan, Sumpah, dan Penguburan Jenazah bagi Umat Beragama yang dihubungkan dengan Aliran Kepercayaan.

6. Surat Edaran Menteri Dalam Negeri no 477/74054 tentang Petunjuk Pengisian Kolom Agama pada Lampiran Surat Keputusan Menteri Dalam Negeri on 221a Tahun 1975.

7. Surat Menteri Dalam Negeri kepada para Gubernur/ KDH Tingkat I dan para Bupati/ Walikotamadya seluruh Indonesia, no 477/ 286/ 1980 tentang Pencabutan Perkawinan bagi para Penghayat Kepercayaan kepada Tuhan Yang Maha Esa.

8. Surat Jaksa Agung kepada Menteri Agama RI uap. Dirjen Bimas Islam dan Urusan Haji No. B-397/ D.I.2980 perihal Perkawinan antara Penganut Sapto Darmo di Daerah kantor Kabupaten Bojonegoro.

9. Surat Menteri Agama kepada Menteri Dalam Negeri no. B.VI/ 5996/ 1980 perihal Perkawinan, Kartu Penduduk dan Kematian para Penghayat Kepercayaan kepada Tuhan Yang Maha Esa.

10. Radiogram atau Telegram Menteri Agama dan Menteri Dalam Negeri kepada Gubernur/ KDH Tingkat I Seluruh Indonesia dan Kakanwil Departemen Agama Seluruh Indonesia on 470.071/ 6380/ SJ.MA/ 610/ 1980

56 Musdah Mulia, Hubungan Agama dan Negara dalam Rangka Menjamin Kebebasan Beragama di Indonesia, dalam buku Mempercakapkan Relasi Agama dan Negara, (Yogyakarta: Pustaka Pelajar, 2011), hlm. 163-165. 
11. Keputusan Menteri Dalam Negeri on 221a Tahun 1975 tentang Pencatatan Perkawinan dan Perceraian.

12. Keputusan Jaksa Agung RI No: KEP-108/ J.A./ 5/ 1984 tentang Pembentukan Tim Koordinasi Pengawasan Aliran Kepercayaan Masyarakat.

13. Instruksi Menteri Agama RI No.4 Tahun 1978 tentang Kebijaksanaan mengenai Aliran-Aliran Kepercayaan.

14. Instruksi Menteri Agama No.8 Tahun 1979 tentang Pembinaan, Bimbingan dan Pengawasan terhadap Organisasi dan Aliran dalam Islam yang bertentangan dengan Ajaran Islam.

15. SKB Menteri Agama dan Menteri Dalam Negeri No. 1/ BER/ mdn-mag/ 1969 tentang Pelaksanaan Tugas Aparatur Pemerintahan dalam Menjamin Ketertiban Pelaksanaan Keagamaan.

Dalam kaitan hubungan antara agama dengan Ideologi, Indonesia dengan Ideologi Pancasila lebih bersifat substantif, tidak formalistik. Dengan demikian, agama seharusnya ditempatkan sebagai ruh atau jiwa. Oleh karena itu tidak boleh muncul bentuk formalisme agama, tetapi yang muncul adalah jiwanya. Pola hubungan ini bagaikan ruh dengan badan. Kedua-duanya tidak bisa dipisahkan antara badan dengan ruh. ${ }^{57}$

\section{Simpulan}

Selama periode kekuasaan Orde Lama dan Orde Baru, perlindungan hukum atas agama lokal belum maksimal, bahkan terkesan setengah-setengah. Hanya 6 (enam) agama yang secara sah diakui oleh negara, sedangkan agama lokal belum memperoleh kepastian hukum. Perlu ada pendekatan baru dalam mengintepretasikan ulang perlindungan hukum atas hak konstitusional warga negara dalam memeluk agama-agama lokal di Indonesia.

Langkah konkrit tersebut dengan cara melakukan evaluasi dan pembentukan peraturan perundang-undangan yang lebih menjamin dan melindungi hak hak konstitusional warga negara, terutama hak beragama dan berkeyakinan. Evaluasi dan pembentukan peraturan perundang-undangan tersebut harus berdasar nilai kebebasan, keadilan, dan persamaan dalam bingkai negara hukum yang menegakkan supremasi hukum. Dengan demikian, hukum bukan sekedar alat untuk mewujudkan ketertiban tetapi membawa kesejahteraan dan keadilan bagi seluruh rakyat.

Disimpulkan bahwa hubungan agama dan negara di Indonesia bersifat substansial, artinya dalam agama terdapat ajaran dan nilai yang bersifat substantial. Hal ini berarti dalam agama terdapat nilai yang bersifat substantif yang mengandung prinsip etis dan moral bermasyarakat dan bernegara. Nilai-nilai agama menjadi acuan dan pedoman dalam menjalankan dan melaksanakan kehidupan masyarakat dan politik kenegaraan. Dengan demikian, negara Indonesia adalah negara berkeTuhanan Yang Maha Esa, dengan tipe negara Ketuhanan Yang Maha Esa menurut dasar kemanusiaan yang adil dan beradab. 


\section{DAFTAR PUSTAKA}

\section{Buku}

Anshari, Endang Saifuddin. Piagam Jakarta 22 Juni 1945 dan Sejarah Konsensus Nasional antara Nasionalis Islami dan Nasionalis "Sekuler" tentang Dasar Negara Republik Indonesia 1945-1959. Jakarta: Rajawali, 1986.

Aritonang, Jan S. Sejarah Perjumpaan Gereja dan Islam di Indonesia, Soegeng Hardiyanto, dkk (Eds), Agama dalam Dialog (Pencerahan, Perdamian dan Masa Depan). Jakarta: BPK Gunung Mulia, 2003.

Bellah, Robert N. The Broken Covenant: American Civil Religion in Time of Trial. Chicago: University of Chicago Press, 1992.

Coleman, John. An American Strategic Theology. New York: Paulist Press, 1982.

Darmodiharjo, Darji. Pancasila dalam Beberapa Perspektif. Jakarta: Aries Lima, 1983.

Dhakidae, Daniel. Cendekiawan dan Kekuasaan dalam Negara Orde Baru. Jakarta: Gramedia Pustaka Utama, 2003.

Durkheim dalam Abdullah dkk. Agama dan Kearifan Lokal Dalam Tantangan Global. Yogyakarta: Pustaka Pelajar, 2008.

Grim, Jhon A. Indigenous Tradition and Ecology. USA: Yale University, Center for Respect of Life and Environment, published in Earth Ethics 10, no.1, Fall 1998.

Hadikusuma, Hilman. Antropologi Agama Bagian I (Pendekatan Budaya terhadap Aliran Kepercayaan, Agama Hindu, Budha, Kong $\mathrm{Hu} \mathrm{Cu}$, di Indonesia). Bandung: Citra Aditya Bakti, 1993.

Hidayat, Komaruddin dalam M. Thoyibi, Yayah Khisbiyah \& Abdullah Aly (Eds). Sinergi Agama dan Budaya Lokal: Dialektika Muhammadiyah dan Seni Lokal. Malang: Muhammadiyah University Press, 2003.

Hidayat, Nurkholis dkk. Peradilan KasusKasus Kebebasan Beragama dan Berkeyakinan (Rangkuman 8 Studi Kasus: Dampai, Pencapaian, Hambatan, dan Strategi). Jakarta: LBH Jakarta, 2011.

Kholisoh, Nur. Demokrasi Aja Kok Repot. Yogyakarta: Pohon Jaya, 2012.

Lubis, M. Ridwan. Sukarno dan Modernisme Islam. Depok: Komunitas Bambu, 2010

MD, Moh. Mahfud. Hukum dan Pilar-Pilar Demokrasi. Yogyakarta: Gama Media, 1999.

Mulia, Musdah. Hubungan Agama dan Negara dalam Rangka Menjamin Kebebasan Beragama di Indonesia, dalam buku Mempercakapkan Relasi Agama dan Negara. Yogyakarta: Pustaka Pelajar, 2011. 
Rahardjo, Iman Toto K. dan Herdianto WK (Eds). Bung Karno Wacana Konstitusi dan Demokrasi: Kenangan 100 Tahun Bung Karno. Jakarta: Grasindo, 2001. Rousseau, Jean-Jacques. Terjemahan G.D.H. Cole. On Social Contract. New York: Dover Publications, 2003.

Setiawan, Chandra. Keragaman Budaya Spiritual sebagai Pemersatu Bangsa dalam buku Laporan Gelar Budaya Spiritual dan Kepercayaan Komunitas Adat. Jakarta: Direktorat Jenderal Nilai Budaya Seni dan Film, Direktorat Kepercayaan Terhadap Tuhan Yang Maha Esa, 2006.

Smith, Donald Eugene. Agama dan Modernisasi Politik: Suatu kajian analitis. Bandung: Rajawali, 1985.

Subagya, Rachmat. Agama Asli Indonesia.

Jakarta: Sinar Harapan dan Yayasan Cipta Loka Caraka,1981.

Sutanto, Trisno S. Dkk. Merayakan Kebebasan Beragama (Bunga Rampai 70 Tahun Djohan Effendi). Jakarta: ICPR dan Kompas, 2009.

Tabrani, M. Dalam Indonesia Merdeka: SoalSoal Minoritoit. Jakarta: Sin Po, 1950. Thaba, Abdul Aziz. Islam dan Negara dalam Politik Orde Baru. Jakarta: Gema Insani Press, 1996.

Wahid, Abdurrahman. Islam Kosmopolitan: Nilai-Nilai Indonesia dan Transformasi Kebudayaan. Jakarta: The Wahid Institute, 2007.
Wahid, Abdurrahman. Mengurai Hubungan Agama dan Negara. Jakarta: Gramedia, 1999.

Yamin, Muh. Risalah Sidang Badan Penyidik Usaha-Usaha Persiapan Kemerdekaan Indonesia (BPUPKI). Jakarta: Panitia Persiapan Kemerdekaan Indonesia (PPKI), Sekretariat Negara Republik Indonesia, 1992.

\section{Jurnal}

Fittrya, Laylatul. "Tionghoa Dalam Diskriminasi Orde Baru Tahun 1967-2000”. AVATARA, e-Journal Pendidikan Sejarah, Fakultas Ilmu Sosial Universitas Negeri Surabaya, Vol. 1, No. 2, (Mei 2013): 163.

Hadi, Sofyan. "Relasi dan Reposisi Agama dan Negara (Tatapan Masa Depan Keberagamaan Di Indonesia)". Jurnal Millah Vol. X, No 2, (Februari 2011): 235.

Pramudya, Wahyu. "Pluralitas Agama: Tantangan "Baru" bagi Pendidikan Keagamaan di Indonesia". Varitas, Vol. 6, (2005): 277.

Sukamto, Amos. "Ketegangan Antar Kelompok Agama pada Masa Orde Lama sampai Awal Orde Baru: Dari Konflik Perumusan Ideologi Negara Sampai Konflik Fisik". Jurnal Teologi Indonesia Vol. 1, No. 1, (Juli 2013): 27. 


\section{Makalah}

Asasriwarni. Undang-Undang No. 1 / PNPS/ th. 1965 tentang Pencegahan Penyalahgunaan dan/atau Penodaan Agama dari Perspektif Agama di Indonesia. Makalah disampaikan pada Kegiatan Kajian Putusan Mahkamah Konstitusi tentang Pencegahan Penyalahgunaan dan/ atau Penodaan Agama terhadap UUD 1945, Senin, 28 Juni 2010 di Hotel Inna Muara Padang, yang diadakan oleh Kementerian Hukum dan HAM RI (Direktorat Jenderal Perundang-undangan) Jakarta, hlm. 4.

\section{Naskah Internet}

Ghifarie, Ibn dan Dudi. "Hubungan NegaraAgama, Bagaikan Ruh dengan Badan”. http://www.ppsuinsgdbdg. ac.id/2011/07/hubungan-negaraagama-bagaikan-ruh-dengan-badan/. Diakses 8 Desember 2013.

Gunaryo, Achmad. "Kebijakan Kementerian Agama Dalam Pembinaan Kerukunan
Umat”. http://sultra.antaranews.com/ berita/264132/kebijakan-kementerianagama-dalam-pembinaan-kerukunanumat. Diakses 26 Juni 2013.

Hutagalung, Batara R. "Ajaran Konghuchu Diakui Kembali Sebagai "Agama Resmi” Indonesia. Bagaimana dengan Agama-Agama Asli Nusantara?". http://batarahutagalung.blogspot. co.id/2006/06/ajaran-konghuchudiakui-kembali.html. Diakses 10 Maret 2013

Kholiluddin, Tedi. "Agama Sipil Sebagai Fenomena Episodik (Problem dan Tantangan Agama Sipil di Indonesia)”. http://cdn.salihara.org/media documents $/ 2013 / 09 / 11 / \mathrm{m} / \mathrm{a} / \mathrm{makalah}_{\text {_ }}$ tedi_kholiludin_agama_sipil.pdf. Diakses 7 Desember 2013.

Syam, H. Nur. "NU, Pancasila Dan Civil Religion”, http://pensa-sb.info/ wp-content/uploads/2011/01/NU_ and_Civil_Religion.pdf. Diakses 7 Desember 2013. 